\title{
In vitro Development of Murine Embryos in presence of Campylobacter fetus
}

\author{
Desarrollo de Embriones Murinos in vitro en Presencia de Campylobacter fetus
}

Catena, M.*; Teruel, M.**; Morán, P.*; Chiapparrone, M..; Echevarria, H.* \& Soto, P.*

\begin{abstract}
CATENA, M.; TERUEL, M.; MORÁN, P.; ChIAPPARRONE, M.; ECHEVARRIA, H. \& SOTO, P. In vitro development of murine embryos in presence of Campylobacter fetus. Int. J. Morphol., 31(4):1168-1174, 2013.

SUMMARY: Bovine campylobacteriosis caused by Campylobacter fetus is associated with reproductive losses. The knowledge about the mechanisms of bacterial pathogenesis is limited, then a murine experimental model is proposed. BALB/c females and males were used. Two-cell embryos were cultured in Ham-F10 as control group (CG). Treatment groups were constituted by the addition of Cfv 1 and 3, or Cff 2 and 5. Morulae were placed in Ham-F10 (CG); treatment groups were constituted by the addition of Cfv27, CFF (cellfree filtrate) and Brucella broth (BB). Blastocysts were cultured in MEM (CG); challenge group were constituted by the addition of Cfv 27. Differentiation, hatching, hatched, adhesion and expansion were evaluated. Results were analyzed by Chi ${ }^{2}$ test. In two-cell embryo, the differentiation rate was not modified when the study strains were added ( $\mathrm{p}>0.05)$. The differentiation rate at $24 \mathrm{~h}$ for embryos at the morula stage was lower for BB, Cfv, and CFF, compared with CG ( $p<0.05)$. After 48 h culture, no differences were observed in blastocyst formation for $\mathrm{Cfv}$ and $\mathrm{BB}$, compared to $\mathrm{CG}(\mathrm{p}>0.05)$. However, the differentiation rate for the CFF group was lower than for $\mathrm{CG}(\mathrm{p}<0.05)$. At 48 and $72 \mathrm{~h}$, the hatching rate was higher in CFF and Cfv groups than in CG ( $<<0.05)$. Differences were not detected in blastocyst cultures. In conclusion, under these experimental conditions, Cf was not detrimental to the development of murine embryos. Efforts will be intensified to establish in vitro infection models that reproduce their pathogenicity.
\end{abstract}

KEY WORDS: Campylobacteriosis; Blastocyst; Morulae; in vitro; Mouse.

\section{INTRODUCTION}

Bovine genital campylobacteriosis is one of the most important venereal diseases in Argentina (Campero, 2002). Campylobacter fetus venerealis (Cfv) and Campylobacter fetus fetus (Cff) are the causative agents of this disease, which is characterized by producing embryonic death and occasional abortion in cattle (Clark, 1971; Hoffer, 1981; Garcia et al., 1983; Hum, 1987). Campylobacter fetus (Cf) is highly adapted to mucosal surfaces (Hu \& Kopecko, 2000) and bacterial population structure is clonal. Cfv is thought to represent a bovine clone of $\mathrm{Cf}$ (Gorkiewics et al., 2010). It is considered that $\mathrm{Cf}$ pathogenic mechanisms are related not only to the effects of bacterial virulence but also to the participation of the host immune response. Several reports suggest that $\mathrm{Cf}$ virulence factors are the cause of embryonic mortality. Some virulence factors that have been associated with the generation of changes in the uterine as well as in the oviductal environment are the microaerophilic property of the bacteria and the production of mucinases. Such changes interfere with the normal embryo development during free life, causing a delay in the implantation and, at a later stage, they lead to embryo death (Hoffer; Garcia et al.; Hum; Joens et al., 2010). However, several works on in vitro fertilization of bovine oocytes carried out in the presence of $\mathrm{Cfv}$ show that fertilization and early embrionary development would not be affected (Bielanski et al.).

Campylobacter fetus produces direct or indirect damage to the host cell through different mechanisms such as adhesion (Chiapparrone et al., 2011), invasion (Hu \& Kopecko, 2008; Larson et al., 2008) and production of cytotoxins (Casadevall \& Pirofski, 2000; Catena et al., 2010). Although these virulence factors have been studied on strains of Campylobacter genus isolated from human beings. No evidence is available to indicate whether $\mathrm{Cf}$ employs similar virulence strategies. The presence of exotoxins has been confirmed in cytotoxicity assays (Johnson \& Lior, 1987;

\footnotetext{
Departamento de Sanidad Animal y Medicina Preventiva, Facultad de Ciencias Veterinarias, Universidad Nacional del Centro de la Provincia de Buenos Aires (UNCPBA), Buenos Aires, Argentina.

** Departamento de Ciencias Biológicas, Facultad de Ciencias Veterinarias UNCPBA, Buenos Aires, Argentina.
} 
Misawa et al., 1995; Tresierra et al., 1995). In 1993, cytolethal toxins were demonstrated in cultures of CHO cells infected with Cff strains of from bovines, establishing or opening the question on the effect of such cytotoxins on embryos (Ohya et al., 1993).

The absence of genetic tools to manipulate $\mathrm{Cf}$ and the difficulty to carry out studies to investigate the molecular basis of host-bacterial interaction lead to the continuous search for new experimental models (Corbeil, 1980; McCardell et al., 1986; O'Sullivan et al., 1988; Young et al., 2000).

Experimental infection assays were carried out in mice in an attempt to find an alternative experimental model. However, the disease could not be reproduced, Catena $e t$ al. (unpublished data). Considering Animal Welfare legislations and the economic cost of the susceptible hosts (bovines) such model could not be implemented. For that reason it would be important to develop an ex vivo study model to reproduce the natural niche conditions for $\mathrm{Cf}$.

This work proposes to find a mouse model that allows ex vivo study of the Campylobacter fetus pathogenesis at different stages of the early embryonic development.

\section{MATERIAL AND METHOD}

Animals. Female and male mice from our own breeding colony went through a lighting regimen consisting of $12 \mathrm{~h}$ of exposure to light and $12 \mathrm{~h}$ in darkness, for seven days before treatment. Mice were placed in plastic boxes with free access to tap water and were handled according to the Animal Welfare Act. (Resol. 087/02, Faculty of Veterinary Sciences, UNCPBA). Five to eight weeks old, C57BL6 X $\mathrm{BALB} / \mathrm{c}$ females, weighing 20-25 g were superovulated by intraperitoneal injection of 10 IU of equine chorionic gonadotropin (eCG - Novormon ®, Laboratorios Syntex S.A, Argentina) and $48 \mathrm{~h}$ later were injected with $10 \mathrm{IU}$ of human chorionic gonadotropin (hCG, Profasi $®$, Laboratorios Serono, Méjico). Females were mated with 12-14 weeks old, proven fertility BALB/c males. Day one of pregnancy was determined when vaginal plugs were first observed.

Embryos collection. Two-cell embryos were recovered from the oviducts of pregnant females euthanized by cervical dislocation on day 2 of pregnancy. Pre-implantation embryos at morula stage were recovered from the oviducts and uterus of pregnant females euthanized on day 3 of pregnancy and blastocysts were collected from the uterus on day 4 of pregnancy. Embryos were obtained from the oviducts and uterus by flushing with Ham F10 (Gibco BRL, Life Technologies NY, USA) supplemented with $0.4 \%$ of bovine serum albumin (BSA - Sigma Chemical Company, St. Louis, MO, USA) using a 30-g needle on a 1-cc syringe.

Bacterial strains and growth conditions. Cfv 1, Cfv 3 and Cfv 27, and Cff 2 and Cff 5 isolated from the cervical mucus of natural infected heifers were provided by the culture collection of the Laboratory of Clinical and Experimental Microbiology at the Faculty of Veterinary Sciences, UNCPBA. The strains were grown in an anaerobic jar at $37^{\circ} \mathrm{C}$ on Skirrow medium (FA Merck) with Campylobacter selective supplement (Oxoid, USA) and incubated for 3 days in an atmosphere of $10 \% \mathrm{CO}_{2}, 5 \% \mathrm{O}_{2}$ and saturation of $\mathrm{N}_{2}$. The bacterial colonies were swept and washed with PBS ( $\mathrm{pH}$ 7.2), centrifuged and re-suspended in minimum essential medium (MEM-EAGLE, M0643 Sigma-Aldrich, USA) to a final cell concentration of $4.5\left(\mathrm{OD}_{480}\right)$. Gram staining was used to examine the morphology and purity of bacteria; only curved, spiral rods were selected. Spherical shaped bacteria were discarded since this morphology is considered a sign of loss of Campylobacter viability. Stock cultures were maintained at $-70^{\circ} \mathrm{C}$ in $15 \%$ ( $\left.\mathrm{vol} / \mathrm{vol}\right)$ glycerol-tryptose phosphate broth (Merck 13811).

Cell-free filtrate (CFF) was obtained from the supernates of centrifuged (30 min at $3000 \mathrm{~g}$ ) of Cfv 27 culture in Brucella broth. To eliminate bacteria remaining in the supernates, these were either passed through cellulose filters (0.22 micron pore size Millipore Corp., Bedford, MA, USA), or gentamicin was added to a final concentration of $200 \mathrm{mg} / \mathrm{L}$.

Culture procedures. Two-cell embryos were placed into cell culture dishes (Falcon \# 3002 - 60x15 mm) in groups of 15, in $60 \mu \mathrm{L}$ micro-drops of Ham-F10 (Gibco BRL, Grand Island, NY, USA) supplemented with $10 \%$ of calf bovine serum, as control group (n: 45). Treatment groups were constituted by the addition of 1 x $10^{8} / \mathrm{mL}$ of Cfv 1 (n: 45) and Cfv 3 (n: 45), or Cff 2 (n: 45) and Cff 5 (n: 45). Embryos were cultured for 72 hours at $37^{\circ} \mathrm{C}$ under silicon oil (Parafarm®, Argentina) in a humidified atmosphere of $5 \%$ $\mathrm{CO}_{2} / 95 \%$ air. To evaluate the progress of development and embryonic morphology, embryos were checked every $24 \mathrm{~h}$.

Murine morulae were placed into cell culture dishes (Falcon \# 3002 - 60 x 15 mm), in groups of 5, in microdrops $(25 \mu \mathrm{l})$ of Ham-F10 supplemented with $0.4 \%$ of BSA, as control group (CG, n: 97), with $\mathrm{Cfv} 27$ added at $1 \times 10^{8} /$ $\mathrm{mL}$ (Cfv, n: 129), with $0.25 \mu \mathrm{L}$ of their cell-free filtrate (CFF, $\mathrm{n}: 119)$ and with $0.25 \mu \mathrm{L}$ of Brucella broth (BB, n: 94); as treatment groups. Embryos were cultured for $72 \mathrm{~h}$ at $37^{\circ} \mathrm{C}$ under silicon oil (Parafarm ${ }^{\circledR}$, Argentina) in a humidified 
atmosphere of $5 \% \mathrm{CO}_{2} / 95 \%$ air. To evaluate the progress of development and embryonic morphology, embryos were checked every $24 \mathrm{~h}$. Fifty nine good to excellent quality blastocysts were cultured in 6-well cell culture plates (Greiner Bio-One, Cellstar® TC-plate $\mathrm{N}^{\circ}$ 657160). Blastocysts were randomly divided in groups of 4 , and cultured in $2 \mathrm{~mL}$ of MEM supplemented with $10 \%$ of calf bovine serum, as control group (n: 24). Blastocysts were cultured in $1.75 \mathrm{~mL}$ of MEM and a suspension of $0.25 \mathrm{~mL}$ of $\mathrm{Cfv}\left(1 \times 10^{8} / \mathrm{mL}\right.$ of $\left.\mathrm{Cfv} 27\right)$, as challenge group (n: 35$)$, was added. Blastocysts were cultured for $96 \mathrm{~h}$ at $37^{\circ} \mathrm{C}$ in a humidified atmosphere of $5 \% \mathrm{CO}_{2} / 95 \%$ air. To evaluate the in vitro development, embryos were observed daily and sequentially photographed.

Evaluation of in vitro embryo development. In cultures starting with two-cell embryos, the percentage of cell differentiation (number of embryos which reached the blastocyst stage/number of cultured embryos at the two-cell stage per 100) was determined. In embryo cultures started at the morula stage, the percentages of cell differentiation and hatching (number of zona-escaping blastocysts/number of cultured embryos at the morula stage per 100) were determined. To study differentiation rates, morulae were evaluated after culture periods of 24 and $48 \mathrm{~h}$. To evaluate the hatching rate, the embryos were scored after 48 and $72 \mathrm{~h}$ of culture. In cultures started as blastocysts, the percentages of hatched embryos (blastocyst that protruded trough the zona pellucida), adhesion and cellular expansion were determined after 24, 48, 72 and $96 \mathrm{~h}$ of culture. Adhesion was considered when it was not possible to remove the embryos from the bottom of the well and expansion, when multiplication of adhered embryonic cells was observed.

Statistical analysis. Percentages of differentiation, hatching, hatched, adhesion and expansion were analyzed by $\mathrm{Chi}^{2}$. Significant differences were considered when $\mathrm{p}<0.05$.

\section{RESULTS}

Embryos cultured from two-cell stage did not suffer any modification in the differentiation rate at $72 \mathrm{~h}$, when the strains in study were added: Cff 2 (90\%); Cff 5 (100\%); Cfv 1 (100\%); Cfv 3 (90\%). The differentiation rate for the control group was $95 \%(\mathrm{p}>0.05)$.

The differentiation rate at $24 \mathrm{~h}$ for embryos cultured at the morula stage was lower for $\mathrm{BB}, \mathrm{Cfv}$, and $\mathrm{CFF}$, compared with $\mathrm{CG}(\mathrm{p}<0.05)$. After $48 \mathrm{~h}$ of incubation no significant differences were observed in blastocyst formation for $\mathrm{Cfv}$ and $\mathrm{BB}$, with respect to $\mathrm{CG}(\mathrm{p}>0.05)$. However, the differentiation rate for the CFF group was lower than for CG $(\mathrm{p}<0.05)($ Table I).

At $48 \mathrm{~h}$ and $72 \mathrm{~h}$, the hatching rate was higher in $\mathrm{CFF}$ and $\mathrm{Cfv}$ groups than in $\mathrm{CG}(\mathrm{p}<0.05)$. Differences were not detected between BB and CG ( $p>0.05)$ (Table I).

Differences were not detected for the evaluated parameters in blastocyst cultures ( $p>0.05)$ (Figs. 1 and 2).

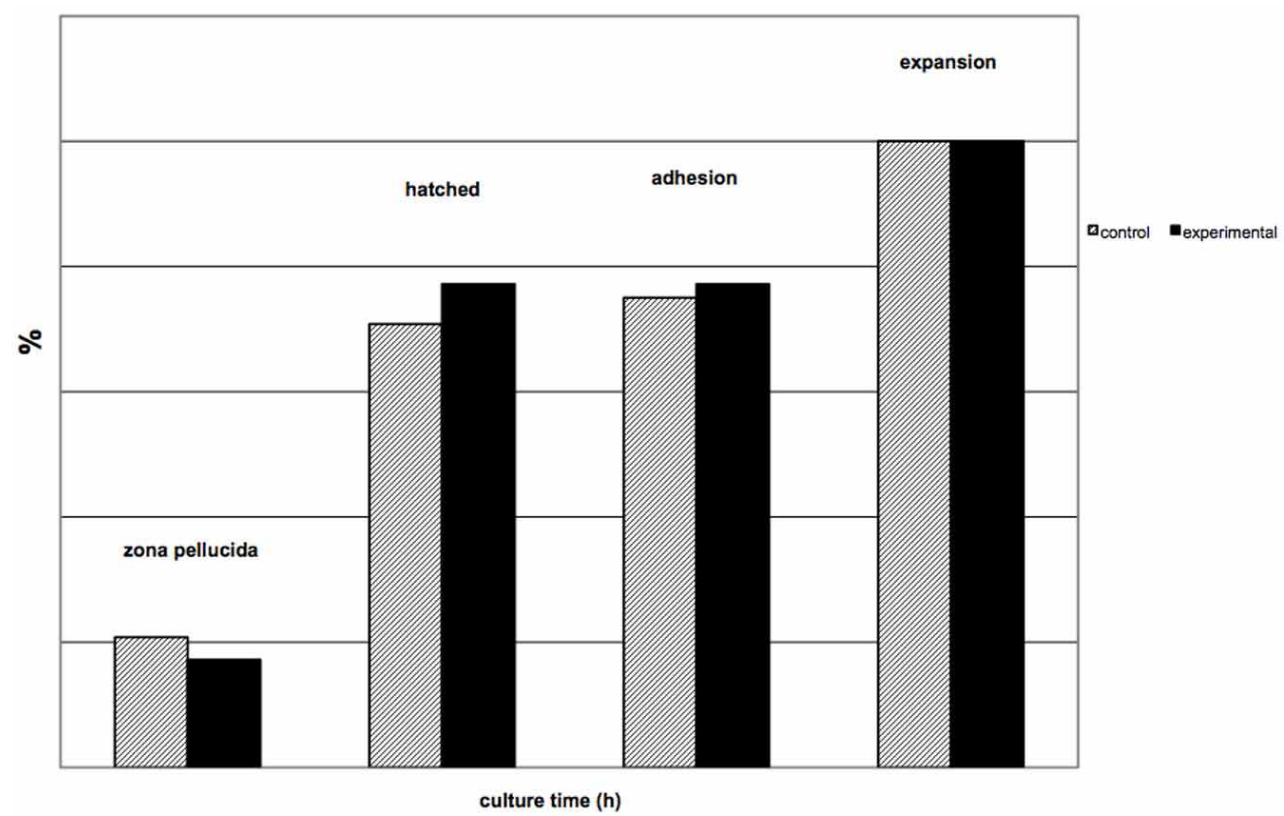

Fig. 1. Development of murine blastocysts cultured in presence or absence of $\mathrm{Cfv}$. 
Table I. Differentiation and hatching rates in murine embryos (at morula stage) cultured in presence or absence of Cfv.

\begin{tabular}{lllll}
\hline & \multicolumn{4}{c}{ Parameters } \\
\cline { 2 - 5 } Groups & \multicolumn{2}{c}{ Differentiation $(\%)$} & \multicolumn{3}{c}{ Hatching $(\%)$} \\
\cline { 2 - 5 } CG & $24 \mathrm{~h}$ & $48 \mathrm{~h}$ & $48 \mathrm{~h}$ & $72 \mathrm{~h}$ \\
\cline { 2 - 5 } BB & $82.5^{\mathrm{a}}$ & $89.6^{\mathrm{a}}$ & $49.4^{\mathrm{a}}$ & $65.5^{\mathrm{b}}$ \\
$C f v$ & $67.0^{\mathrm{b}}$ & $76.2^{\mathrm{ab}}$ & $44.5^{\mathrm{a}}$ & $66.2^{\mathrm{ab}}$ \\
$\mathrm{CFF}$ & $66.6^{\mathrm{b}}$ & $78.3^{\mathrm{ab}}$ & $71.2^{\mathrm{b}}$ & $79.2^{\mathrm{ac}}$ \\
\hline
\end{tabular}

CG: control group; BB: Brucella broth; Cfv: addition of Campylobacter fetus at 1 x $108 \mathrm{Cfv} / \mathrm{mL}$; CFF: cell-free filtrate. Different letters within the same column, show significant differences $(\mathrm{p}<0.05)$

\section{DISCUSSION}

The host and tissue tropism of Cf subspecies offers a unique opportunity to understand the molecular bases of habitat selection. The direct effect of $\mathrm{Cf}$ on the bovine embryo is one of the aspects of the pathogenesis which has not even elucidated (Garcia \& Brooks, 1993). According to this, we have developed models that allow us to study the effect of $\mathrm{Cff}$ and $\mathrm{Cfv}$ on their target cells, mainly bovine endometrial and vaginal cells (Chiapparrone et al., 2011).

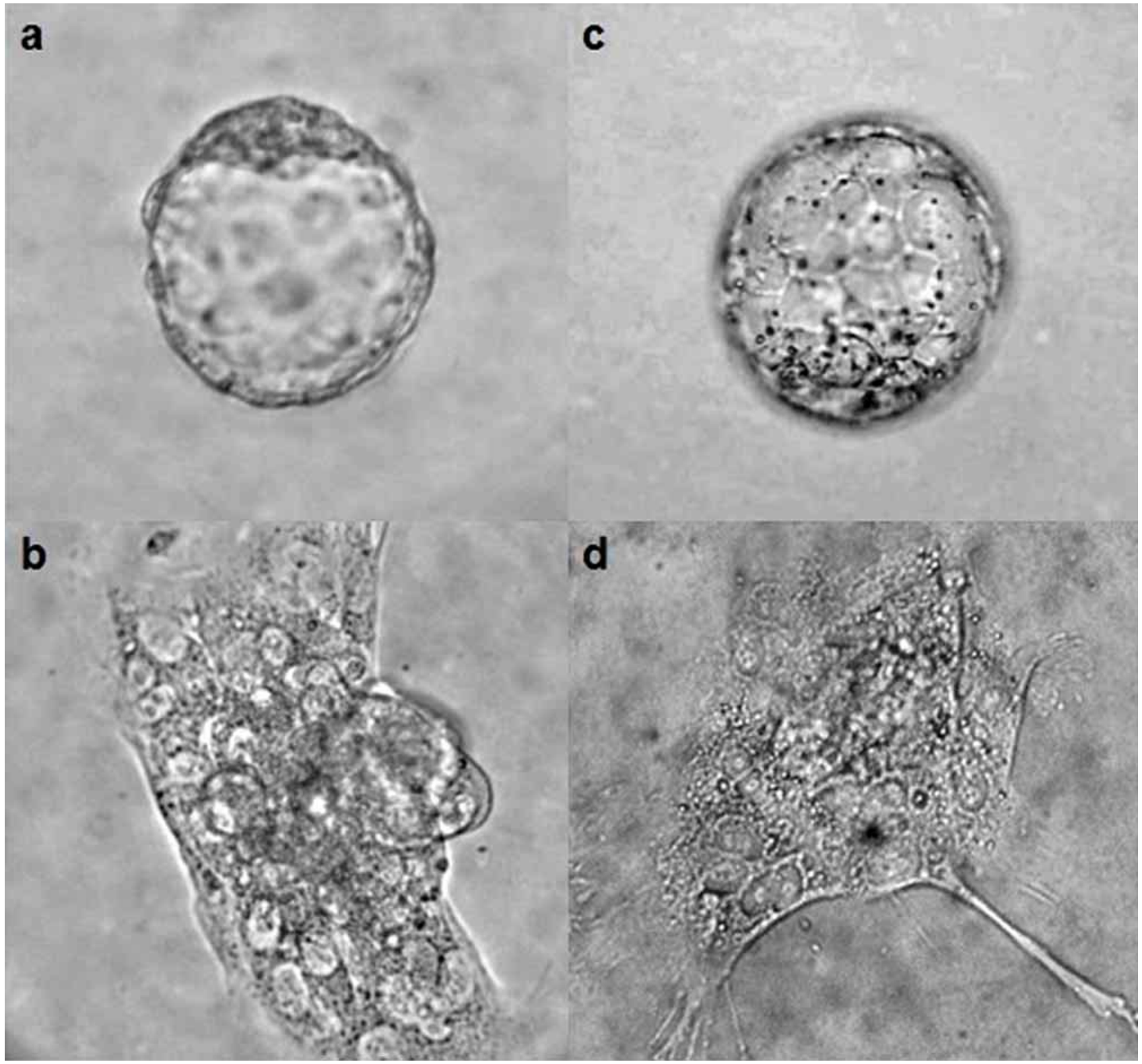

Fig. 2. Photomicrographs of adhesion and cellular expansion in blastocysts at starter culture and $96 \mathrm{~h}$ later. Control embryo: a) $0 \mathrm{~h}$ and b) $96 \mathrm{~h}$ of culture; challenge embryo: Campylobacter fetus added at $\left.1 \times 10^{8} \mathrm{Cfv} / \mathrm{mL}, \mathrm{c}\right) 0 \mathrm{~h}$ and d) $96 \mathrm{~h}$ of culture. 
The development of an ex-vivo model, such as the in vitro murine embryo culture allowed us to evaluate the action of $\mathrm{Cf}$ at the different stages of embryo development. Our results show that, in the presence of $\mathrm{Cfv}$, there is a decrease in the differentiation rate during the first 24 culture hours. However, at later time-points, differences with the control group are not detected. On the basis of this observation, it can be inferred that the formation of the embryonic tissues derived from the internal cell mass, as well as those constituting the fetal placenta derived from the trophectoderm, is not affected by Cfv. It is possible to relate these findings with those from assays carried out with experimentally infected female bovines which were diagnosed as non-pregnant by ultrasonography; although the presence of trophoblastic cells in uterine histological sections (indicating mother-embryo interaction) was observed (Catena et al., 2001). However, when the embryos were cultured in Ham F10 with the addition of cell-free filtrate, the differentiation rate resulted negatively affected at 24 and 48 culture hours. This may be a consequence to the effect of bacterial toxins present in the filtrate, as it was observed in bovine endometrial and vaginal cells (Chiapparrone et al., 2011) and in cell line cultures (Catena et al., 2003; Chiapparrone et al., 2009).

The presence of $\mathrm{Cf}$ or the cell-free filtrate was not detrimental to the hatching process. This information is valuable considering that this process is an indicator of embryo viability and it is closely related to the embryo implantation capacity (Gordon \& Dapunt, 1993).
The analysis of the relation between the presence of Cfv and embryo expansion once the zona pellucida was lost, revealed that the virulence factors of the strain used did not produce any evident interference in the development of the embryo. This is in agreement with in vitro studies on bovine oocytes, which determined that the presence of $\mathrm{Cfv}$ did not affect the fertilization or the early embryo development (Bielanski et al., 1994; Joens et al.), as it was observed for other reproductive pathogens (Bielansky \& Dubuc, 1994; Bielanski et al., 2004).

The results obtained from studies with ex-vivo models and pregnant bovine females (Catena et al., 2003) suggest that the determining factor of embryo death would be the bacteria-host interaction and not a direct effect of the bacteria alone (Beer \& Billingham, 1979; Croy, 2001).

In conclusion, under these experimental conditions, $\mathrm{Cfv}$ and Cff were not detrimental to the early development of murine embryos cultured in vitro. Efforts will be intensified to understand the effects of CFF, specifically to establish in vitro infection models that reproduce the pathogenicity of $\mathrm{Cf}$ in order to identify the virulence factors that affect embryo cells.

\section{ACKNOWLEDGEMENTS}

Chiapparrone, Laura is a holder of fellowship from CONICET, Argentina

CATENA, M.; TERUEL, M.; MORÁN, P.; CHIAPPARRONE, M.; ECHEVARRIA, H. \& SOTO, P. Desarrollo de embriones murinos in vitro en presencia de Campylobacter fetus. Int. J. Morphol., 31(4):1168-1174, 2013.

RESUMEN: La campilobacteriosis bovina caudada por Campylobacter fetus produce pérdidas reproductivas existiendo poca información de los mecanismos de patogenicidad de dicha bacteria, por lo cual se propone un modelo utilizando ratones BALC/c. Embriones de dos células fueron cultivados en Ham-F10: grupo control (GC), los grupos experimentales fueron adicionados con las cepas Cfv 1, Cfv 3, Cff 2 y Cff 5. Mórulas fueron cultivadas en Ham-F10 (GC); los grupos tratados recibieron Cfv27, CFF (filtrado libre de células) y caldo Brucella (BB). Blastocistos fueron cultivados en MEM (GC) y MEM más Cfv 27 (grupo desafiado). Se evaluó: diferenciación, "hatching”, "hatched", adhesión y expansión. Los resultados fueron analizados por Chi². En embriones de dos células, la diferenciación no fue modificada por acción de las cepas evaluadas ( $>$ > 0,05). Para embriones en estadío de mórula, la diferenciación a las 24 h de cultivo fue menor para BB, Cfv, y CFF, comparado con el GC ( $p<0,05$ ). Luego de 48 h de cultivo, no hubo diferencias entre Cfv, BB, y CG (p > 0,05), no obstante para el grupo CFF la diferenciación fue menor al CG ( $p<0,05)$. El porcentaje de "hatching" (48 y 72 h de cultivo), fue mayor en los grupos CFF y Cfv comparado con el GC (p < 0,05). La adición de Cfv 27 no modificó el desarrollo de blastocistos. En el modelo propuesto, Cf no afectó negativamente el desarrollo embrionario. Futuros trabajos serán necesarios para establecer un modelo de infección in vitro en pos de reproducir su patogenicidad.

PALABRAS CLAVE: Campylobacteriosis; Blastocisto; Mórula; in vitro; Ratón.

\section{REFERENCES}

Beer, A. \& Billingham, R. Maternal immunological recognition mechanism during pregnancy. Ciba Found. Symp., 64:293-322, 1979.
Bielanski, A.; Sampath, M.; Gradil, C.; Eaglesome, M. \& García, M. In vitro fertilization of bovine ova in the presence of Campylobacter fetus subsp. venerealis. Repr. Dom. Anim., 29(6):488-93, 1994. 
Bielanski, A. \& Dubuc, C. In-Vitro Fertilization and Culture of Ova From Heifers Infected with Bovine Herpesvirus-1 (BHV1). Theriogenology, 41(6):1211-7, 1994.

Bielanski, A.; Ghazi, D. \& Phipps-Toodd, B. Observations on the fertilization and development of preimplantation bovine embryos in vitro in the presence of Tritrichomonas foetus. Theriogenology, 61(5):821-9, 2004.

Campero, C. Pérdidas ocasionadas por las enfermedades venéreas de los bovinos. Rev. Idia Bs. As., 21(2):127-31, 2002.

Casadevall, A. \& Pirofski, L. A. Host-Pathogen Interactions: Basic Concepts of Microbial Commensalism, Colonization, Infection and Disease. Infect. Immun., 68(12):6511-8, 2000.

Catena, M.; Callejas, S.; Soto, P.; Aba, M.; Echevarría, H.; Monteavaro, C. \& Mazzolli, A. Efectos de la infección experimental con Campylobacter fetus venerealis sobre la preñez temprana en vaquillonas. In. Vet., 5(1):37-44, 2003.

Catena, M.; Chiapparrone, M.; Teruel, M.; Morán, P. \& Soto, P. Biological characterization of cytolethal distending toxins produced by Campylobacter fetus venerealis. Proc. VII RAPAVE, Buenos Aires, Argentina, Jul 6-8, 2010. p.104.

Catena, M.; Soto, P.; Echevarría, H.; Monteavaro, C.; Callejas, S.; Aba, M. \& Mazzolli, A. Campilobacteriosis genital bovina: modelo experimental en vaquillonas durante el período embrionario. Proc. XVII Reunión de la Asociación Latinoamericana de Producción Animal (ALPA), La Habana, Cuba, Nov. 19-23, 2001. pp.2145-49.

Chiapparrone, L.; Catena, M.; Morán, P.; Teruel, M.; Echevarría, H. \& Soto, P. Modelos de estudio in vitro para Campylobacter fetus. Proc. IV Encuentro de Biólogos en Red, Mar del Plata, Argentina, Oct 30, 2009. p.24.

Chiapparrone, M.; Morán, P.; Pasucci, J.; Echevarría, H.; Monteavaro, C.; Soto, P.; Rodríguez, E. \& Catena, M. Quantitative analysis of Campylobacter fetus venerealis adhesion to bovine reproductive tract cell cultures. Braz. J. Vet. Res. Anim. Sci., 48(1):73-8, 2011.

Clark, B. Review of bovine vibriosis. Australian Vet. J., 47(3):103-7, 1971.

Corbeil, L. B. Criteria for development of animal models of diseases of reproductive system. Am. J. Pathol., 101(3 Suppl.):S241-53, 1980.

Croy, B. A. Where now for the Th1/Th2 paradigm of the gestacional uterus? J. Reprod. Immunol., 51(1):1-2, 2001.

García, M.; Eaglesome, M. \& Rigby, C. Campylobacters important in veterinary medicine. Vet. Bull., 53:793-818, 1983.

García, M. \& Brooks, B. Campylobacter. In: Gyles, C.; Prescott,
J.; Songer, J. \& Thoen, C. (Eds.). Pathogenesis of Bacterial Infections in Animals. Ames, Iowa State University Press, 1993. pp.262-72.

Gordon, J. W. \& Dapunt, U. Restoration for normal implantation rates in mouse embryos with a hatching impairment by use of a new method of assisted hatching. Fertil. Steril., 59(6):1302-07, 1993.

Gorkiewicz, G.; Kienesberger, S.; Schober, C.; Scheicher, S.; Gully, C.; Zechner, R. \& Zechner, E. A genomic island defines subspecies-specific virulence features of the host-adapted pathogen Campylobacter fetus subsp. venerealis. J. Bacteriol., 192(2):502-17, 2010.

Hoffer, M. A. Bovine Campylobacteriosis: A Review. Can. Vet. J., 22(11):327-30, 1981.

Hu, L. \& Kopecko, D. Interactions of Campylobacter with eukaryotic cells: Gut luminal colonization and mucosal invasion mechanisms. In: Nachamkin, I. \& Blaser, M. J. (Eds.). Campylobacter. Washington D.C., ASM Press, 2000. pp.191-215.

Hu, L. \& Kopecko, D. Human Host Cell Entry. In: Nachamkin, I.; Szymanski, C. M. \& Blaser, M. J. (Eds.). Washington D.C., ASM Press, 2008. pp.297-313.

Hum, S. Bovine abortion due to Campylobacter fetus. Aust. Vet. J., 64(10):319-20, 1987.

Joens, L.; Haesebrouk, F. \& Pasmans, F. Campylobacter and Helicobacter. In: Gyles, C.; Prescott, J.; Songer, J. \& Thoen, C. (Eds.). Pathogenesis of Bacterial Infections in Animals. Iowa, Blacwell Publishig, 2010. pp.483-501.

Johnson, W. M. \& Lior, H. A new heat-labile cytolethal distending toxin (CLDT) produced by Campylobacter spp. Microb. Pathog., 4(2):115-26, 1987.

Larson, C.; Christensen, J.; Pacheco, S.; Minnich, S. \& Konkel, M. Campylobacter jejuni secretes proteins via the flagellar type III secretion system that contribute to host cell invasion and gastroenteritis. In: Nachamkin, I.; Szymanski, C. M. \& Blaser, M. J. (Eds.). Campylobacter. Washington D.C., ASM Press, 2008. pp.315-32.

McCardell, B. A.; Madden, J. M. \& Stanfield, J. T. A mouse model for the measurement of virulence of species of Campylobacter. J. Infec. Dis., 153(1):177, 1986.

Misawa, N.; Ohnishi, T.; Itoh, K. \& Takaashi, E. Cytotoxin detection in Campylobacter jejuni of human and animal origin with three tissue culture assay systems. J. Med. Microbiol., 43(5):354-9, 1995.

Ohya, T.; Tominaga, K. \& Nakazawa, M. Production of cytolethal distending toxin (CLDT) by Campylobacterfetus subsp. fetus isolated from calves. J. Vet. Med. Sci., 55(3):507-9, 1993. 
CATENA, M.; TERUEL, M.; MORÁN, P.; CHIAPPARRONE, M.; ECHEVARRIA, H. \& SOTO, P. In vitro development of murine embryos in presence of Campylobacter fetus. Int. J. Morphol., 31(4):1168-1174, 2013

O'Sullivan, A. M.; Doré, C. J. \& Coid, C. R. Campylobacters and impaired fetal development in mice. J. Med. Microbiol., 25(1):7-12, 1988.

Tresierra, A.; Fernandez, H.; Reinhardt, G.; Tadich, N.; Cabezas, X. \& Zamora, J. Detección de efectos toxigénicos en cepas de Campylobacter jejuni y Campylobacter coli aisladas de bovino. Arch. Med. Vet., 27:53-9, 1995.

Young, V. B.; Dangler, C. A.; Fox, J. G. \& Schauer, D. B. Chronic atrophic gastritis in SCI mice experimentally infected with Campylobacter fetus. Infect. Immun., 68(4):2110-8, 2000.
Correspondence to:

Dra. María Catena

Área de Enfermedades Infecciosas

Facultad de Ciencias Veterinarias

Universidad Nacional del Centro

de la Provincia de Buenos Aires

Tandil, Provincia de Buenos Aires

ARGENTINA

Email: mcatena@vet.unicen.edu.ar

Received: 09-03-2013

Accepted: 03-08-2013 